Henri Michaux. Studien zum literarischen Werk 
Eberhard Geisler

\section{Henri Michaux}

Studien zum literarischen Werk 
Die Deutsche Bibliothek - CIP-Einheitsaufnahme

Geisler, Eberhard

Henri Michaux : Studien zum literarischen Werk /

Eberhard Geisler. -Stuttgart; Weimar : Metzler 1993

(Romanistische Abhandlungen ; 7)

ISBN 978-3-476-00863-3 ISBN 978-3-476-03436-6 (eBook)

DOI 10.1007/978-3-476-03436-6

NE: GT

Dieses Werk einschließlich aller seiner Teile ist urheberrechtlich geschützt.

Jede Verwertung außerhalb der engen Grenzen des Urheberrechtsgesetzes

ist ohne Zustimmung des Verlages unzulässig und strafbar.

Das gilt insbesondere für Vervielfältigungen, Übersetzungen,

Mikroverfilmungen und die Einspeicherung und

Verarbeitung in elektronischen Systemen.

(C) 1993 Springer-Verlag GmbH Deutschland

Ursprünglich erschienen bei J.B. Metzlersche Verlagsbuchhandlung

und Carl Ernst Poeschel Verlag GmbH in Stuttgart 1993 


\section{Inhalt}

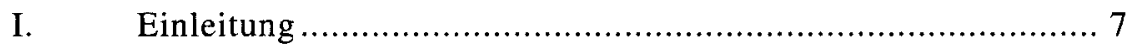

II. An der Schwelle zur symbolischen Ordnung.

Eine psychoanalytische Lektüre

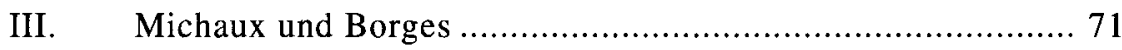

IV. Michaux und Jünger ........................................ 110

V. $\quad$ Averse de vide«.

$\mathrm{Zu}$ den Texten des Spätwerks ..................................... 186

VI. Bibliographie .................................................... 233 